\title{
Sebaceous Gland Carcinoma Masquerading as a Chalazion in a 18 Year Old Girl
}

\author{
Meenakshi Wadhwani*, Rachna Meel and Seema Kashyap \\ Ophthalmology Scientist (D), AlIMS, New Delhi, India
}

\begin{abstract}
Neoplasms of the sebaceous glands may masquerade as benign lesions resulting in delay in diagnosis. Their presentation may vary from sebaceous cell adenoma to sebaceous cell carcinoma. Worldwide, sebaceous cell carcinoma is the second most common eyelid malignancy after basal cell carcinoma. It commonly occurs in seventh decade of life. We report the clinical and histopathological findings of an 18-years-old girl presenting to us with sebaceous cell carcinoma in absence of any predisposing factors.
\end{abstract}

Keywords: Sebaceous cell carcinoma; Sebaceous gland; Risk factors

\section{Introduction}

Worldwide, Sebaceous Gland Carcinoma (SGC) constitutes 3.2\% of all eyelid malignant tumors and $0.8 \%$ of all eyelid tumors. However, studies from India and China report a significantly higher incidence of SGC ( $28 \%$ of all eyelid malignancies) [1]. The reported mortality rate in SGC of eyelid is $22 \%$ [1]. SGC most commonly arises from the meibomian glands, occasionally from the glands of Zeis or Moll, and from sebaceous glands in caruncle. However, the cell of origin may not be certain in $50-60 \%$ of cases [2,3]. Sebaceous cell carcinomas typically occur in women, more often in the seventh decade of life, with a predisposition for upper eyelid margin. Although SGC of eyelid are rare in young, they may be seen in young patients who have previously received radiation to the face. Herein, we report a case of SGC occurring in an eighteen-years- old girl with no predisposing risk factors.

\section{Case Report}

An eighteen-years-old girl presented to us with a nodule on her right upper eye lid for past 3 months. There was history of recurrent painful swelling on the same site for the past six months. A diagnosis of chalazion was made outside for which she was advised warm compress and eyelid massage. There was no history of fever, cough or weight loss. Her general physical and systemic examinations were within normal limits.

On ocular examination, a well-defined mass measuring $3 \times 3 \mathrm{~mm}$ was seen on lateral part of her right (OD) upper eyelid. It involved the eyelid margin with loss of eyelashes in that area. The mass was yellow in color with cheesy appearance; was non tender and adherent to the underlying tarsus. Rest of the ocular examination was within normal limits. Systemic examination was uneventful.

Clinical examination was suggestive of eyelid malignancy. An excision of tumor with wide surgical margins was performed under local anesthesia. The histopathological examination of the specimen revealed a diffuse collection of pleomorphic medium sized cells with moderate amount of cytoplasm, vesicular nuclei and prominent nucleoli: a fair number of mitotic figures were present with atypical mitosis. This was suggestive of a poorly differentiated SGC (Figure 1). At the last follow up of two years the patient is free of any tumor.

\section{Discussion}

Sebaceous gland tumor of the eyelid may arise from meibomian glands, glands of Zeis or glands associated with the caruncle. It has varied clinical presentation that may masquarade blepharoconjunctivitis, chalazion and superior limbic keratoconjunctivitis [4]. SGC may have

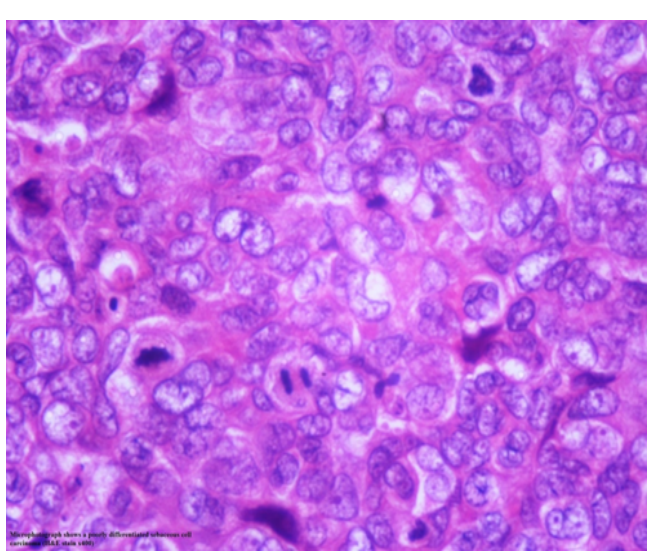

Figure 1: Microphotography shows a poorly differentiated sebaceous cell carcinoma (H\&E stain $\times 400)$.

multifocal origin and pagetoid spread (spreading of malignant cells to epithelium that appears to be separate from main tumour) that increases likelihood of recurrence [4,5]. It is a slow growing malignancy of older age, with female predisposition. However, rarely it has been reported in children and young adults.

In the young, SGC of eyelid is usually associated with prior exposure to radiation [2,6-9]. It is extremely rare to find SGC in young patients with no known risk factors for tumours like retinoblastoma or underlying predisposing syndromes like MTS [4]. We could find only 6 cases of SGC presenting in younger age in literature (Table 1). Five of these six patients, had predisposing risk for SGC. The current case did not have any history of radiotherapy, which makes it even more unusual. Also, the current case highlights the importance of early signs of malignancy that may help in early detection of eyelid malignancy in small eyelid tumours. In the current case, there was loss of cilia that pointed towards possible malignancy. Early diagnosis and consequent

*Corresponding author: Meenakshi Wadhwani, Ophthalmology Scientist (D), AlIMS, New Delhi, India, Tel: +91-11-26588500/26588700; Fax: +91-1126588663/26588641; E-mail: mkgang08@gmail.com

Received May 20, 2015; Accepted July 20, 2015; Published July 27, 2015

Citation: Wadhwani M, Meel R, Kashyap S (2015) Sebaceous Gland Carcinoma Masquerading as a Chalazion in a 18 Year Old Girl. J Clin Case Rep 5: 562 doi:10.4172/2165-7920.1000562

Copyright: (c) 2015 Wadhwani M, et al. This is an open-access article distributed under the terms of the Creative Commons Attribution License, which permits unrestricted use, distribution, and reproduction in any medium, provided the original author and source are credited. 
Citation: Wadhwani M, Meel R, Kashyap S (2015) Sebaceous Gland Carcinoma Masquerading as a Chalazion in a 18 Year Old Girl. J Clin Case Rep 5: 562. doi:10.4172/2165-7920.1000562

\begin{tabular}{|c|c|c|c|}
\hline $\begin{array}{c}\text { Number of } \\
\text { patients }\end{array}$ & $\begin{array}{c}\text { Age range } \\
\text { (years) }\end{array}$ & Risk factors & References \\
\hline 9 & 8,12 & $\begin{array}{c}\text { Bilateral Retinoblastoma } \\
\text { (Radiotherapy) }\end{array}$ & {$[4,6]$} \\
\hline 2 & 17,28 & $\begin{array}{c}\text { Unilateral Retinoblastoma } \\
\text { (Radiotherapy) }\end{array}$ & {$[9]$} \\
\hline 1 & 27 & Radiotherapy & {$[3]$} \\
\hline
\end{tabular}

2. Sihota R, Tandon K, Betharia SM, Arora R (1996) Arch Ophthalmol 114: 108109.

3. Song A, Carter KD, Syed NA, Song J, Nerad JA (2008) Sebaceous cell carcinoma of the ocular adnexa: clinical presentations, histopathology, and outcomes. Ophthal Plast Reconstr Surg 24: 194-200.

4. Sung D, Kaltrelder AS, Fernandes FG (2011) Early onset sebaceous carcinoma Diagnostic pathology 6: 81-85.

Table 1: Occurrence of sebaceous gland carcinomas with various risk factors in age group less than 30 years.

surgical therapy of sebaceous carcinoma of the eyelid leads to a better outcome and higher survival rates. To conclude, we report a rare case of SGC occurring in a young patient with no predisposing factors: early diagnosis by picking up subtle signs of malignancy helped us avoid disease progression, need for a larger reconstruction and tumour metastasis.

\section{References}

1. Ni C, Searl SS, Kuo PK, Chu FR, Chong CS, et al. (1982) Sebaceous cell carcinomas of the ocular adnexa. Int Ophthalmol Clin 22: 23-61.

5. Condon GP, Brownstein S, Codère F (1985) Sebaceous carcinoma of the eyelid masquerading as superior limbic keratoconjunctivits. Arch Ophthalmol 103: $1525-1529$

6. Kivela T, Asko Seljavaara S, Pihkala U, Hovi L, Heikkonen J (2001) Sebaceous carcinoma of the eyelid associated with retinoblastoma. Ophthalmology 108 : 1124-1128.

7. Chao AN, Shields CL, Krema H, Shields JA (2001) Outcome of patients with periocular sebaceous gland carcinoma with and without conjunctival intraepithelial invasion. Ophthalmology 108: 1877-1883.

8. Shields JA, Shields CL (1988) Sebaceous carcinoma of the glands of Zeis Ophthal Plast Reconstr Surg 4: 11-14.

9. Wali UK, Mujaini Al (2010) Sebaceous gland carcinoma of the eyelid. Oman J Ophthalmol 3: 117-121. 